\title{
Finishing Cattle in All-Natural and Conventional Production Systems
}

\author{
Zachary K. Smith ${ }^{1 *}$, Peter T. Anderson' ${ }^{2}$, Bradley J. Johnson ${ }^{3}$ \\ ${ }^{1}$ Department of Animal Science, South Dakota State University, Brookings, SD, USA \\ ${ }^{2}$ Midwest PMS, LLC, Firestone, CO, USA \\ ${ }^{3}$ Department of Animal and Food Sciences, Texas Tech University, Lubbock, TX, USA \\ Email: ^zachary.smith@sdstate.edu
}

How to cite this paper: Smith, Z.K., Anderson, P.T. and Johnson, B.J. (2020) Finishing Cattle in All-Natural and Conventional Production Systems. Open Journal of Animal Sciences, 10, 237-253. https://doi.org/10.4236/ojas.2020.102013

Received: January 7, 2020

Accepted: February 2, 2020

Published: February 5, 2020

Copyright (c) 2020 by author(s) and Scientific Research Publishing Inc. This work is licensed under the Creative Commons Attribution International License (CC BY 4.0).

http://creativecommons.org/licenses/by/4.0/

\section{Open Access}

\begin{abstract}
Beef cattle producers in the North America have a variety of production and marketing options and must choose the best production system for their situation. This review describes considerations involved in choosing between feeding cattle conventionally versus feeding them in programs that prohibit the use of certain technologies. Data from peer-reviewed journals, extension publications, nutritional consultants, governmental organizations, and feed companies were used to construct this review. Most cattle in North America are fed in conventional production systems. Conventional beef production systems typically use steroidal implants, ionophores, and beta-adrenergic agonists to improve animal productivity; as well as feed grade and injectable antimicrobials to control, treat or prevent disease and improve animal health. These technologies have been shown to lower the cost of production, allowing for beef to be competitive in the global protein market. Some consumers have expressed a preference for beef produced without these technologies. These "All-natural" (AN) cattle may bring a premium price in the market. The economic impact of differing productions systems can be described in relation to 1) cost of production, 2) operating costs of the feedlot, 3) price paid for feeder calves, and 4) price received for fed cattle. Conventional production provides the most favorable outcome for factors 1,2 , and 3, while AN production provides the most favorable outcome for item 4 . There are also industry wide and societal aspects related to differing beef production systems related to health and safety of beef, land use, and cost of production allowing for a greater share of the global protein market. Technologies used in conventional production are critical tools to North American beef production. Differences in efficiencies between each type of non-conventional production systems must be re-captured in added premiums when cattle are marketed and sold. Premiums for AN cattle are enticing, but the true differences in the cost of production between the AN and conventional cattle must
\end{abstract}


be evaluated in order for a producer to make the correct decision for their operation.

\section{Keywords}

All-Natural, Beef, Beta-Adrenergic Agonist, Conventional, Ionophore, Production Systems, Steroidal Implant

\section{Introduction}

Beef cattle producers must choose the best production system for their situation. Conventional production systems use steroidal implants, ionophores, and beta-adrenergic agonists to improve animal productivity; feed grade and injectable antimicrobials are also used to control, treat or prevent disease and improve animal health. Conventional systems also allow feeding of animal by-products and genetically modified feedstuffs, which may not be allowed in some natural programs and are never allowed in organic cattle feeding systems. These management differences between conventional and "All-natural" (AN) lower the cost of production in favor of conventional production. However, some consumers have expressed a preference for beef produced without these technologies.

Since the European Union banned the use of growth promoting compounds in animals intended for human consumption in 1989 [1] [2], and increased demand domestically, the natural-fed segment of the US beef market has grown. The definition of the term "natural" within the context of beef production channels is more ambiguous than the definition of "organic" or non-hormone treated cattle (NHTC). According to the US Department of Agriculture-Food Safety Inspection Service (USDA-FSIS), all fresh beef qualifies to carry a "natural" label, because fresh beef is only minimally processed, and contains no artificial ingredients, or chemical preservatives. Thus, understanding what is meant in reference to "natural" requires some clarification.

Organic and NHTC beef production are clearly defined. The Agricultural Marketing Service of the USDA (USDA-AMS) has an organic certification that requires cattle be managed under a prescribed protocol from the last third of gestation throughout the entire life of the animal [3]. Additionally, the USDA-NHTC program has clearly defined management practices and is verified through USDA audits.

Unlike the USDA-Organic and NHTC programs, AN beef programs are not USDA certified. These AN programs are primarily managed by branded beef marketing groups and involve a third-party audit of participating entities. Thus, for cattle fed in AN programs the conditions of each individual marketing program dictate the types of feed, feed additives, as well as other pharmaceutical and growth technologies that can be used during production. Most AN programs fit "Never Ever 3" (NE3) specifications, meaning that the cattle have 1) never received exogenous hormones, 2) have never received antibiotics (injectable or in 
feed), and 3) never been fed animal by-products. For a period of time, NE3 specifications were audited by the USDA, but the agency ceased that oversight in November of 2015. Nonetheless, NE3 is a commonly used term among natural beef programs and is often closely aligned with their specifications. Throughout this paper, anything that is not produced conventionally or organically will be referred to as either AN or NHTC. For these examples, AN will match NE3 specifications, NHTC will allow use of any technology except certain growth promotants (Table 1). The objective of this review is to compare technology effects on production systems used in North American beef production to allow for individual organizations to determine which production system is best for their customers.

\section{Animal Performance and Economic Considerations}

At an individual organization level, the economics of production may differ among conventional, AN, NHTC, and organic systems. These differences are driven by system effects on: 1) cost of production, 2) operating cost of the feedlot, 3) price paid for feeder cattle and 4) price received for fed cattle.

Cost of production. The largest difference in cost of production between programs is the use, or non use of growth promoting technologies. For more than 60 years, US beef cattle producers have safely used various types of growth-enhancing technologies (GETs) to increase carcass leanness, increase average daily gain (ADG), improve feed to gain ratio (F:G), and alter dry matter intake (DMI). Steroidal implants and beta-adrenergic agonists are two technologies that increase production efficiency by enhancing animal growth [4] [5] [6]. Previously diethylstilbestrol was routinely used in US beef production; in other parts of the world, the beta-adrenergic agonist clenbuterol has been used. However, use of these compounds has been discontinued due to human safety concerns. Use of approved technologies is proven to be safe for cattle and consumers of beef, and routinely provides a positive return on investment to the producer [4] [7] [8].

Table 1. Use of technologies by beef marketing program.

\begin{tabular}{|c|c|c|c|c|}
\hline Technology & Organic & All-Natural & $\begin{array}{l}\text { Non-Hormone } \\
\text { Treated Cattle }\end{array}$ & Conventional \\
\hline Steroidal implants & Prohibited & Restricted or not used & Not allowed & Commonly used \\
\hline Estrus suppression (melengestrol acetate) & Prohibited & Restricted or not used & Not allowed & Commonly used \\
\hline Beta-adrenergic agonists & Prohibited & Restricted or not used & Not allowed & Commonly used \\
\hline Feed grade antimicrobials & Prohibited & Prohibited & Allowed & Used as necessary \\
\hline Anthelmintics & Prohibited & Allowed & Allowed & Used as necessary \\
\hline Coccidiostats & Prohibited & Restricted or not used & Allowed & Used as necessary \\
\hline Feeding of animal by-products & Prohibited & Restricted or not used & Allowed & Allowed \\
\hline
\end{tabular}


When considering alternative systems that disallow use of these technologies, it is important to understand potential consequences regarding production losses. Lean, Thompson and Dunshea [5] used a meta-analysis to indicate that the use of zilpaterol hydrochloride can increase hot carcass weight by $15 \mathrm{~kg}$, final BW by $8 \mathrm{~kg}$, and ADG by $0.15 \mathrm{~kg} / \mathrm{d}$ and that ractopamine hydrochloride can increase hot carcass weight by $7.3 \mathrm{~kg}$, final BW by $6.5 \mathrm{~kg}$, and ADG by $0.24 \mathrm{~kg} / \mathrm{d}$. In another meta-analysis conducted by Reinhardt and Wagner [4] estrogen based, steroidal implants increased HCW by $21.4 \mathrm{~kg}$ and ADG by $0.27 \mathrm{~kg} / \mathrm{d}$. Thus, when a producer chooses to utilize a GET, improvements in treated cattle over non-treated cattle are typically in the range of 10\% to 30\% for ADG and 5\% to $20 \%$ for F:G [4] [5] [6] [8].

The use of steroidal implants can alter apparent dietary net energy (NE) for gain values by increasing feed consumption above that required for maintenance and by lessening the caloric content of growth. Steroidal implants alter mature body weight $(\mathrm{BW})$, in turn altering the caloric content of growth at a given $\mathrm{BW}$ relative to a non-implanted animal. Beta-adrenergic agonists lessen the caloric content of growth by acting as either partitioning or repartitioning agents which enhance lean tissue deposition and lessen fat deposition. The use of ionophores can alter apparent dietary NEg values by improving ruminal fermentation and in some cases increased intake such as seen with laidlomycin propionate versus monensin sodium [9]. Thus, differences in cost of production and apparent dietary NE values due to differences in gain that were attributed to the pharmaceutical growth technologies can be assessed.

Differences in cost of production can also be assessed related to differences in feed cost of gain. In an implant study by Smith, Thompson, Hutcheson, Nichols and Johnson [10] steers were administered no implant, a $200 \mathrm{mg}$ trenbolone acetate (TBA) and $40 \mathrm{mg}$ estradiol-17 $\beta\left(\mathrm{E}_{2}\right)$ implant (Revalor-XS) $213 \mathrm{~d}$ prior to harvest, or a $200 \mathrm{mg}$ TBA and $20 \mathrm{mg} \mathrm{E}_{2}$ implant (Revalor-200) $143 \mathrm{~d}$ prior to harvest (Table 2). Monensin sodium and tylosin phosphate were included in the diet. Results from these implant regimens provide insight to what might be expected when cattle are administered no steroidal implant, are given an implant that may be administered for this production window, and an implant administered to steers who became disqualified for an AN feeding program approximately $70 \mathrm{~d}$ into the $200 \mathrm{~d}$ feeding period. The use of implants decreased $(P \leq$ $0.05)$ the feed cost of gain approximately $9.5 \%$ compared to non-implanted steers.

Maxwell et al. (2015) compared AN to conventional production systems. Conventional management approaches including a steroidal implant, ionophore and feed grade antimicrobial along with the use and non-use of zilpaterol $\mathrm{HCl}$ were compared to an AN feeding program. In the AN vs conventional systems comparison, feeding monensin sodium, tylosin phosphate, and administering a steroidal implant decreased the feed cost of gain approximately $21.0 \%$ compared to the AN steers (Table 3). In the same study, when zilpaterol $\mathrm{HCl}$ was fed to another group of conventionally managed steers, there was an approximately $25.0 \%$ decrease in feed cost of gain compared to AN steers. 
Table 2. Feed cost of gain $(\$ / 0.454 \mathrm{~kg})$ in steers not implanted or implanted and fed for 213 d. ${ }^{1}$

\begin{tabular}{ccccc}
\hline & \multicolumn{5}{c}{ Treatment $^{2}$} \\
\hline Item & NI & Revalor-XS & Revalor-200 & SEM \\
\hline Feed Cost of Gain, \$/0.454kg & & & & \\
$\$ 150.00,907-\mathrm{kg} \mathrm{DM}$ & $0.50^{\mathrm{a}}$ & $0.46^{\mathrm{b}}$ & $0.46^{\mathrm{b}}$ & 0.009 \\
$\$ 200.00,907-\mathrm{kg} \mathrm{DM}$ & $0.67^{\mathrm{a}}$ & $0.61^{\mathrm{b}}$ & $0.61^{\mathrm{b}}$ & 0.012 \\
$\$ 250.00,907-\mathrm{kg} \mathrm{DM}$ & $0.84^{\mathrm{a}}$ & $0.76^{\mathrm{b}}$ & $0.77^{\mathrm{b}}$ & 0.015 \\
$\$ 300.00,907-\mathrm{kg} \mathrm{DM}$ & $1.01^{\mathrm{a}}$ & $0.91^{\mathrm{b}}$ & $0.92^{\mathrm{b}}$ & 0.184 \\
\hline
\end{tabular}

${ }^{1}$ Adapted from [10]. ${ }^{2}$ Treatments included: no implant (NI), $200 \mathrm{mg}$ TBA and $40 \mathrm{mg} \mathrm{E} 2$ administered at trial initiation (Revalor-XS) or $200 \mathrm{mg}$ TBA and $20 \mathrm{mg} \mathrm{E} \mathrm{E}_{2}$ administered on d 70 (Revalor-200). ${ }^{\mathrm{a}, \mathrm{b}} \mathrm{Means}$ without a common superscript differ $(P<0.05)$.

Table 3. Feed cost of gain $(\$ / 0.454 \mathrm{~kg})$ for steers fed All-Natural, Conventional, or Conventional with zilpaterol hydrochloride for an average of $136 \mathrm{~d} .^{1}$

\begin{tabular}{cccc}
\hline & \multicolumn{3}{c}{ Treatment $^{2}$} \\
\hline Item & NAT & CONV & CONV-Z \\
\hline Feed Cost of Gain, \$/0.454kg & & & 0.47 \\
\$150.00, 907-kg DM & 0.63 & 0.49 & 0.63 \\
$\$ 200.00,907-\mathrm{kg} \mathrm{DM}$ & 0.83 & 0.66 & 0.78 \\
\$250.00, 907-kg DM & 1.04 & 0.82 & 0.94 \\
$\$ 300.00,907-\mathrm{kg} \mathrm{DM}$ & 1.25 & 0.99 & \\
\hline
\end{tabular}

${ }^{1}$ Adapted from [33]. ${ }^{2}$ Treatments included: all natural (NAT), fed monensin sodium, tylosin phosphate, and administered an anabolic implant under conventional management (CONV), and conventional management + zilpaterol $\mathrm{HCl}(\mathrm{CONV}-\mathrm{Z})$.

Using raw data from the Thompson, Smith, Corbin, Harper and Johnson [9] study the feed cost of gain was calculated. In this work, cattle were fed four different treatments: no ionophore or feed grade antimicrobial, fed laidlomycin propionate and chlortetracycline for $151 \mathrm{~d}$, fed laidlomycin propionate and chlortetracycline for $119 \mathrm{~d}$ and offered ractopamine $\mathrm{HCl}[300 \mathrm{mg} / \mathrm{head}(\mathrm{hd}) / \mathrm{d}]$ for the final 32 of the $151 \mathrm{~d}$ feeding period, or fed monensin sodium and tylosin phosphate throughout the $151 \mathrm{~d}$ study and ractopamine $\mathrm{HCl}[300 \mathrm{mg} / \mathrm{hd} / \mathrm{d}]$ was fed for the final $32 \mathrm{~d}$ (Table 4). All steers in the study were implanted with a 100 mg TBA and $14 \mathrm{mg}$ estradiol benzoate implant at study initiation. Feeding laidlomycin propionate and chlortetracycline decreased $(P \leq 0.05)$ the feed cost of gain by approximately $6.0 \%$ compared to the control diet. In the same study, feeding laidlomycin propionate and chlortetracycline for $119 \mathrm{~d}$ and ractopamine $\mathrm{HCl}$ the final $32 \mathrm{~d}$, decreased $(P \leq 0.05)$ the feed cost of gain by nearly $6.0 \%$ compared to the control diet. Feeding monensin sodium and tylosin phosphate throughout the study and ractopamine $\mathrm{HCl}$ the final $32 \mathrm{~d}$, decreased $(P \leq 0.05)$ the feed cost of gain by almost $6.0 \%$ compared to the control diet. These examples used a dry diet cost of $\$ 250.00 / 907-\mathrm{kg} D M$, and are only intended as a reference as to what can be expected in regard to technologies that alter F:G, if feed pharmaceutical additives or growth technologies were used, diet cost could increase. Specific ingredient standards and common generally recognized as safe 
compounds (i.e. direct fed microbial, yeast cultures, and organic trace minerals) used in some non-conventional production systems could also increase diet cost versus conventional. Therefore, one must input their own ration cost when comparing systems within their production constraints and level of management. It is important to note that if apparent energy value a diet is increased when pharmaceutical compounds are used, the cost of GET (i.e. ractopamine $\mathrm{HCl}$ ) addition to the diet must be less than the apparent improvement in dietary energy value. If this is the case, the use of pharmaceutical and growth technologies decrease the cost of each unit of energy that is used during production and also decrease the feed cost of gain.

To illustrate a direct comparison of $\mathrm{AN}$ and conventional production systems, closeout summaries from two large commercial feedyards were obtained (Table 5). These two yards typically place cattle of similar genetic merit into their AN/NHTC programs and their conventional feeding program. The differences in $\mathrm{ADG}$ between cattle in the differing programs was $24.61 \%$ and $11.70 \%$ for steers and heifers between $\mathrm{AN}$ and conventional across both feedlots, respectively.

Table 4. Feed cost of gain $(\$ / 0.454 \mathrm{~kg})$ for steers fed differing feed additives for $151 \mathrm{~d} .{ }^{1}$

\begin{tabular}{clllll}
\hline & \multicolumn{5}{c}{ Treatment $^{2}$} \\
\hline Item & CON & LP & LPRH & MT & SEM \\
\hline Feed Cost of Gain, \$/0.454kg & & & & \\
$\$ 150.00,907-\mathrm{kg} \mathrm{DM}$ & $0.43^{\mathrm{a}}$ & $0.40^{\mathrm{b}}$ & $0.40^{\mathrm{b}}$ & $0.40^{\mathrm{b}}$ & 0.005 \\
$\$ 200.00,907-\mathrm{kg} \mathrm{DM}$ & $0.57^{\mathrm{a}}$ & $0.54^{\mathrm{b}}$ & $0.54^{\mathrm{b}}$ & $0.54^{\mathrm{b}}$ & 0.007 \\
$\$ 250.00,907-\mathrm{kg} \mathrm{DM}$ & $0.71^{\mathrm{a}}$ & $0.67^{\mathrm{b}}$ & $0.67^{\mathrm{b}}$ & $0.67^{\mathrm{b}}$ & 0.008 \\
$\$ 300.00,907-\mathrm{kg} \mathrm{DM}$ & $0.86^{\mathrm{a}}$ & $0.81^{\mathrm{b}}$ & $0.81^{\mathrm{b}}$ & $0.81^{\mathrm{b}}$ & 0.010 \\
\hline
\end{tabular}

${ }^{1}$ Adapted from [9]. ${ }^{2}$ Treatments included: no ionophore or antimicrobial (CON), fed laidlomycin propionate $(12.1 \mathrm{mg} / \mathrm{kg} \mathrm{DM})$ and chlortetracycline $(350 \mathrm{mg} / \mathrm{hd} / \mathrm{d})$ for $151 \mathrm{~d}(\mathrm{LP})$, fed laidlomycin propionate $(12.1 \mathrm{mg} / \mathrm{kg} \mathrm{DM})$ and chlortetracycline $(350 \mathrm{mg} / \mathrm{hd} / \mathrm{d})$ for $119 \mathrm{~d}$ and ractopamine $\mathrm{HCl}(300 \mathrm{mg} / \mathrm{hd} / \mathrm{d})$ for the final $32 \mathrm{~d}$ (LPRH), and fed monensin sodium ( $36.4 \mathrm{mg} / \mathrm{kg} \mathrm{DM})$ and tylosin phosphate $(12.1 \mathrm{mg} / \mathrm{kg} \mathrm{DM})$ for $119 \mathrm{~d}$ and ractopamine $\mathrm{HCl}(300 \mathrm{mg} / \mathrm{hd} / \mathrm{d})$ was also included for final $32 \mathrm{~d}(\mathrm{MT}){ }^{\mathrm{a}, \mathrm{b}}$ Means without a common superscript differ $(P<0.05)$.

Table 5. Summary of performance from two commercial feedyards that place cattle of equal genetic merit into their $\mathrm{AN}$ and conventional feeding programs.

\begin{tabular}{ccccccccc}
\hline & \multicolumn{2}{c}{ Steers, Yard A } & \multicolumn{2}{c}{ Heifers, Yard A } & \multicolumn{2}{c}{ Steers, Yard B } & \multicolumn{2}{c}{ Heifers, Yard B } \\
\hline Item & Natural & Conv. & Natural & Conv. & Natural & Conv. & Natural & Conv. \\
\hline Initial BW ${ }^{2}, \mathrm{~kg}$ & 385 & 367 & 360 & 359 & 371 & 367 & 350 & 328 \\
Out BW, kg & 571 & 639 & 575 & 599 & 609 & 689 & 572 & 594 \\
DOF $^{3}$ & 133 & 152 & 150 & 160 & 173 & 202 & 163 & 184 \\
ADG $^{4}, \mathrm{~kg}$ & 1.24 & 1.66 & 1.20 & 1.42 & 1.31 & 1.51 & 1.29 & 1.36 \\
DMI $^{5}, \mathrm{~kg}$ & 9.64 & 9.86 & 9.45 & 9.35 & 10.17 & 9.55 & 9.88 & 8.81 \\
F:G $^{6}$ & 7.75 & 5.93 & 7.86 & 6.58 & 7.79 & 6.34 & 7.69 & 6.5 \\
Death loss, \% & 2.63 & 1.92 & 4.75 & 1.75 & 1.71 & 1.75 & 7.76 & 2.35 \\
\hline
\end{tabular}

${ }^{1}$ Conv. $=$ Conventional management. ${ }^{2} \mathrm{BW}=$ body weight. ${ }^{3} \mathrm{DOF}=$ days on feed. ${ }^{4} \mathrm{ADG}=$ average daily gain. ${ }^{5} \mathrm{DMI}=$ dry matter intake. ${ }^{6} \mathrm{~F}: \mathrm{G}=\mathrm{DMI} / \mathrm{ADG}$. 
When foregoing use of implants during the finishing phase, a producer gives up $10 \%$ to $30 \%$ responses in $\mathrm{ADG}$, but performance loss is not equal across gender groups. Herschler, Edwards, Olmsted, Sheldon, Hale, Preston, Bartle and Montgomery [11] reported that steers and intact heifers administered an implant that contained $200 \mathrm{mg}$ of TBA and $28 \mathrm{mg}$ of estradiol benzoate had improved ADG by $20.9 \%$ and $10.5 \%$ compared to non-implanted controls for steers and intact heifers, respectively. Pritchard and Rust [12] summarized six studies representing 1468 heifers in total [13]-[18]. In their pooled analysis, steroidal implants increased ADG by $10.5 \%$ and $15.7 \%$ compared to non-implanted controls for intact and ovariectomized heifers, respectively. Differing responses between steers, intact heifers, and ovariectomized heifers when steroidal implants are used is most likely due to differences in endogenous estradiol-17 $\beta$ production between steers, intact heifers, and ovariectomized heifers [19] [20].

Sex differences in ADG responses to a steroidal implant suggest that heifers might be better suited for feeding in AN programs than steers. This is most likely due to a lower response curve (i.e. improvement over a non-use animal), that in turn can reduce the penalty for not capturing the potential of the technology. Heifers are inherently more expensive to feed as indicated by purchase price discrimination [21] [22]. However, a marginal improvement in gain or efficiency is more valuable in a heifer than a steer. The marginal improvement in gain or efficiency coupled with the magnitude differential must be considered in order to determine if heifers are better suited for AN production compared to steers.

The question of genetic capability is significant because of substantial differences inherent in the feeder cattle population. Often, cattle being fed in AN, NHTC, and USDA-Organic programs are cattle that represent the surest guarantee of traceability available to producers. It is not uncommon for these AN cattle to have ADG similar to conventionally raised animals. Initially, one might be pleased with the performance of their AN cattle compared to their conventional cattle if ADG is similar between both groups; however, this is not a fair comparison. If an implanted steer gains $1.63 \mathrm{~kg} / \mathrm{d}$, he would likely have gained approximately $1.36 \mathrm{~kg} / \mathrm{d}$ without the steroidal implant (i.e. a $20 \%$ response in ADG due to the steroidal implant). Likewise, an AN steer that gains $1.59 \mathrm{~kg} / \mathrm{d}$ without the use of a steroidal implant would be expected to gain $1.91 \mathrm{~kg} / \mathrm{d}$ (i.e. a $20 \%$ increase in ADG) if administered a steroidal implant which has been demonstrated by others [23]. Thus, feeding in an AN or NHTC program may limit the return on investment for the animal with the best genetics available. When all things are considered (i.e. fallout rate and salvage weight of the fallout animal), economic performance might have been better using the technology on the valuable calf as compared to managing the animal under the guidelines of an AN or similar program.

Substantial variation in the feeder cattle population exists, data in Table 6 and Table 7 show the range in value (deads-in) for closed lots of $306 \mathrm{~kg}$ heifers and $306 \mathrm{~kg}$ steers. These data were obtained from a random subpopulation of all closeouts in recent years for customers of Midwest PMS, based upon sex (heifers 
Z. K. Smith et al.

Table 6. Range in value of 306-kg feeder heifers (deads-in).

\begin{tabular}{|c|c|c|c|c|c|c|c|c|c|c|}
\hline $\mathrm{PHV}^{1}$ & Lots & Initial $\mathrm{BW}^{2}, \mathrm{~kg}$ & Out BW, kg & $\mathrm{DOF}^{3}$ & $\mathrm{ADG}^{4}, \mathrm{~kg}$ & $\mathrm{DMI}^{5}, \mathrm{~kg}$ & $F: G^{6}$ & Mortality, \% & Value, \$/hd & vs the average \\
\hline 550 & 2 & 297 & 540 & 143 & 0.61 & 8.46 & 14.39 & 28.81 & 558.66 & -382.79 \\
\hline 600 & 3 & 306 & 545 & 159 & 0.78 & 10.53 & 13.96 & 20.69 & 591.65 & -349.80 \\
\hline 650 & 5 & 305 & 505 & 177 & 0.69 & 7.77 & 11.44 & 15.43 & 637.52 & -303.93 \\
\hline 700 & 8 & 302 & 541 & 181 & 0.96 & 8.81 & 9.27 & 12.38 & 713.55 & -227.90 \\
\hline 750 & 34 & 303 & 545 & 177 & 1.02 & 8.50 & 8.37 & 11.18 & 758.50 & -182.95 \\
\hline 800 & 71 & 303 & 543 & 177 & 1.12 & 8.47 & 7.63 & 7.83 & 803.23 & -138.22 \\
\hline 850 & 176 & 304 & 542 & 175 & 1.22 & 8.57 & 7.08 & 4.81 & 853.15 & -88.30 \\
\hline 900 & 444 & 304 & 546 & 172 & 1.33 & 8.78 & 6.63 & 2.53 & 903.64 & -37.81 \\
\hline 950 & 833 & 307 & 555 & 168 & 1.43 & 8.97 & 6.27 & 1.56 & 951.32 & 9.87 \\
\hline 1000 & 523 & 308 & 573 & 170 & 1.53 & 9.30 & 6.09 & 1.10 & 995.83 & 54.38 \\
\hline 1050 & 144 & 309 & 597 & 175 & 1.63 & 9.72 & 5.97 & 0.71 & 1043.18 & 101.73 \\
\hline 1100 & 11 & 311 & 611 & 172 & 1.72 & 9.73 & 5.63 & 0.71 & 1087.54 & 146.09 \\
\hline 1150 & 3 & 310 & 618 & 196 & 1.56 & 7.83 & 4.95 & 0.00 & 1138.82 & 197.37 \\
\hline Total & 2257 & 307 & 559 & 171 & 1.41 & 9.00 & 6.45 & 2.30 & 941.45 & 0.00 \\
\hline
\end{tabular}

${ }^{1} \mathrm{PHV}=$ Per head value; index value (by $50.00 \$ /$ head increments) of a dollar per head breakeven purchase price. ${ }^{2} \mathrm{BW}=$ body weight. ${ }^{3} \mathrm{DOF}=$ days on feed. ${ }^{4} \mathrm{ADG}=$ average daily gain. ${ }^{5} \mathrm{DMI}=$ dry matter intake. ${ }^{6} \mathrm{~F}: \mathrm{G}=\mathrm{DMI} / \mathrm{ADG}$.

Table 7. Range in value of 306-kg feeder steers (deads-in).

\begin{tabular}{ccccccccccc}
\hline $\mathrm{PHV}^{1}$ & Lots & Initial BW & , kg Out BW, $\mathrm{kg}$ & $\mathrm{DOF}^{3}$ & $\mathrm{ADG}^{4}, \mathrm{~kg}$ & $\mathrm{DMI}^{5}, \mathrm{~kg}$ & $\mathrm{~F}: \mathrm{G}^{6}$ & Mortality, \% Value, \$/hd vs the average \\
\hline 600 & 2 & 300 & 626 & 196 & 0.87 & 9.06 & 10.73 & 22.92 & 612.32 & -396.79 \\
650 & 3 & 310 & 564 & 67 & 0.67 & 7.67 & 11.60 & 25.24 & 653.51 & -355.60 \\
700 & 7 & 306 & 540 & 194 & 0.77 & 7.79 & 10.19 & 14.80 & 692.63 & -316.48 \\
750 & 15 & 307 & 558 & 180 & 0.98 & 8.47 & 8.61 & 13.18 & 749.42 & -259.69 \\
800 & 31 & 306 & 566 & 184 & 1.09 & 8.62 & 7.94 & 10.28 & 798.10 & -211.01 \\
850 & 63 & 305 & 580 & 189 & 1.22 & 8.73 & 7.17 & 7.51 & 855.37 & -153.74 \\
900 & 128 & 306 & 584 & 193 & 1.31 & 8.83 & 6.78 & 4.57 & 903.43 & -105.68 \\
950 & 306 & 305 & 593 & 193 & 1.39 & 8.89 & 6.41 & 3.56 & 952.01 & -57.10 \\
1000 & 474 & 306 & 609 & 194 & 1.49 & 9.08 & 6.10 & 2.49 & 1000.38 & -8.73 \\
1050 & 536 & 307 & 629 & 198 & 1.59 & 9.36 & 5.92 & 1.63 & 1049.32 & 40.21 \\
1100 & 288 & 308 & 652 & 202 & 1.68 & 9.75 & 5.81 & 1.09 & 1095.67 & 86.56 \\
1150 & 74 & 308 & 679 & 212 & 1.73 & 9.90 & 5.74 & 0.86 & 1139.45 & 130.34 \\
1200 & 13 & 308 & 722 & 236 & 1.74 & 9.98 & 5.75 & 0.66 & 1198.34 & 189.23 \\
1250 & 3 & 308 & 691 & 212 & 1.80 & 8.74 & 4.86 & 0.27 & 1252.21 & 243.10 \\
Total & 1943 & 307 & 618 & 196 & 1.51 & 9.22 & 6.19 & 2.74 & 1009.11 & 0.00 \\
\hline
\end{tabular}

${ }^{1} \mathrm{PHV}=$ Per head value; index value (by $50.00 \$$ head increments) of a dollar per head breakeven purchase price. ${ }^{2} \mathrm{BW}=$ body weight. ${ }^{3} \mathrm{DOF}=\mathrm{days}$ on feed . ${ }^{4} \mathrm{ADG}=$ average daily gain. ${ }^{5} \mathrm{DMI}=$ dry matter intake. ${ }^{6} \mathrm{~F}: \mathrm{G}=\mathrm{DMI} / \mathrm{ADG}$. 
and steers) and placement weight (initial BW of 295 to $317 \mathrm{~kg}$ ). These data can provide a benchmark for what the actual feeder cattle population in the US entails. An understanding the value the current feeder cattle population is capable of generating can prove useful when making decisions related to differing production programs. The value for each lot was calculated using a standardized feed and sale price. Out weight was used along with the standard sale price to calculate revenue. After revenue was calculated, cost of production (i.e. feed consumed, medicine and processing costs, and other miscellaneous costs) was subtracted in order to calculate a breakeven purchase value of the entire lot as feeders. This value was then divided by number of hd placed to calculate a per hd value (PHV). The PHV is the total amount that could have been paid for each animal in the lot at placement in order to breakeven. The data are indexed in $\$ 50 / \mathrm{PHV}$ increments to generate the rows of mean data presented in Table 6 and Table 7.

Given the price and cost assumptions, the average value of all $306 \mathrm{~kg}$ feeder heifers was $\$ 941.45 / \mathrm{hd}$ and a $\$ 139.47 / 45.4 \mathrm{~kg}$ purchase breakeven (Table 6). The two lowest value heifer lots had PHV of $\$ 558.66 / \mathrm{hd}$ and $\$ 85.42 / 45.4 \mathrm{~kg}$ purchase breakeven as feeders. The two low value lots (\$550 PHV) had mean ADG of 0.61 $\mathrm{kg} / \mathrm{d}, \mathrm{F}: \mathrm{G}$ of 14.39 , and $28.81 \%$ mortality and were worth $\$ 382.79 /$ hd less as feeders than the average. Alternatively, there were three exceptional lots ( $\$ 1150$ $\mathrm{PHV}$ ) that had average $\mathrm{PHV}$ of $\$ 1138.82 /$ hd and a purchase breakeven of $\$ 166.49 / 45.4 \mathrm{~kg}$ as feeders. These three exceptional lots of heifers had mean ADG of $1.57 \mathrm{~kg} / \mathrm{d}, \mathrm{F}: \mathrm{G}$ of 4.95 , and no mortality. These three $\$ 1150 \mathrm{PHV}$ lots of heifers were worth $\$ 197.37 /$ hd more than the average as feeders and $\$ 580.16 /$ hd more as feeders than the lowest PHV index lots.

It is the same story for $306 \mathrm{~kg}$ feeder steers (Table 7) except the range in value is even greater at $\$ 639.90 / \mathrm{hd}$ more as feeders between the lowest and greatest PHV groups. The greatest PHV indexing steer lots had exceptional gain, a heavy market weight, minimal mortality, and they also exhibited outstanding F:G. These higher quality cattle have a higher purchase breakeven as feeders. High value feeder cattle stay alive, eat, and get very large, they also convert feed to gain very efficiently. However, without known and repeated use of a source of cattle, these traits are very difficult to ascertain a priori and if this was possible, then realized purchase price would reflect the differential in prices. If these traits were easily identified a priori this could mean that a conventional feeder has an opportunity to attempt to purchase these cattle away from the AN feeder without having to be concerned with fallout cattle from the primary market or changes in marketing channel due to seasonal demands.

Operating cost of the feedlot. Operating costs are increased by implementation of an AN program. Compliance costs can be substantial. Most AN programs require specific documentation of how the cattle were managed. This level of documentation is not required for marketing through conventional channels. Labor and equipment required to move fallout cattle represent an added cost. 
Cattle fed in the USDA-Organic program are strictly limited to organic feedstuffs and no constituents of the diet may be obtained from another animal. Other AN programs are not typically required to be fed organic feedstuffs and some allow the use of animal by-products in feed. A feedlot that chooses to feed some pens under conventional management and other pens in the same feedlot under management practices that prohibit the use of some feed additives might easily fail to comply with program requirements if all cattle are fed using the same equipment. The analytical assays used to check for drug compliance during auditing are conducted under high pressure liquid chromatography. Most AN programs only require a signed affidavit, however, sensitive analytical procedure can detect traces of drugs in the ppm $(\mathrm{mg} / \mathrm{kg})$ to $\mathrm{ppb}(\mu \mathrm{g} / \mathrm{kg})$ range. Minimizing cross contamination can become impossible when using the same equipment if there is a "zero-tolerance" policy. Even if there is not a "zero-tolerance" policy, flushing and feed management can become very difficult with the level of surveillance capable using the employed analytical techniques. If the same system cannot be used to feed conventional and AN cattle, the cost of implementing the AN feeding program increases. One opportunity is to exclusively feed AN cattle at a designated facility in the organization, however, this only works for operations with multiple facilities and may not work for all of them. This practice would minimize the risk of being out of compliance, but cost of production increases because of transportation of fallout cattle to their new home.

Another cost that must be considered is the lost economic opportunity for the feedlot, if selling feed is their primary source of revenue. Due to intake stimulation by implants, implanted cattle typically consume $5 \%$ to $6 \%$ more feed per day than non-implanted cattle of similar weight [4]. In addition, the added weight of implanted cattle further increases feed, as intake per unit BW will likely remain unchanged. For a custom cattle feeder, these NHTC cattle will consume less of the feed that is for sale. Producers who charge feed markup should consider higher margins on feed sold to NHTC cattle to equalize revenue to the feedlot. Chute charges or specific handling charges for dealing with fallout cattle could be considered as well.

Pen size and occupancy is another consideration. In an ideal situation, cattle destined for an AN program would not be co-mingled with cattle from other sources in order to fill a pen. Feedyard profitability is maximized with full pens but that often requires feeding cattle from multiple sources together since the average cow herd size in the US is 43.5 hd [24]. Large pens (i.e. greater than 150 hd) may not allow the flexibility required to keep cattle from different sources separated. Keeping cattle sorted by sex and source will help minimize morbidity and is critical to effectively producing cattle destined for an AN program. Smaller capacity pens could prove valuable to the AN cattle feeder allowing for greater flexibility in acquiring single and known source cattle. If smaller capacity pens are not available to the cattle feeder, then comingling of program eligible cattle might need to occur to optimize pen occupancy. 
The type of diet that is fed to cattle in various marketing programs should be considered. Cattle in an AN program that prohibits the use of an ionophore and steroidal implants, may be better suited for a moderate energy finishing diet (for example, $58 \mathrm{Mcal} \mathrm{NEg}$ [net energy for gain] $/ 45.4 \mathrm{~kg}$ ). This strategy of a lower NEg finisher might be better suited for the AN beef animal because, without the use of a steroidal implant, frame can be grown in this individual by using a lower energy finisher as compared to a $69 \mathrm{Mcal} \mathrm{NEg} / 45.4 \mathrm{~kg}$ [25] diet in order to generate more BW at harvest if using homegrown or economically purchase roughage sources. Although slowing finishing rate can have significant consequences to inventory turnover and unit cost, because of less dilution of fixed costs, it in turn produces heavier weight cattle at harvest [26]. The latter option produces smaller cattle at maturity [26]. Finally, when feeding a finisher with a higher roughage inclusion, the influence of monensin on meal size and frequency might not be as important compared to feeding a low roughage inclusion, $69 \mathrm{Mcal}$ $\mathrm{NEg} / 45.4 \mathrm{~kg}$ finisher [25]. The type of diet fed to AN destined cattle should match the available feedstuffs and the management skills of the cattle feeder when use of pharmaceutical and growth technologies are not permitted.

Geographic location is another consideration. Feeding operations in the Midwest and High Plains can be profitable for very different reasons. For example, yards in the High Plains typically have favorable weather and pen conditions, but greater feed costs compared to Midwestern yards. Large yards may have dedicated personnel to manage risk when opting to feed cattle that can qualify for an AN program. Alternatively, Midwestern feeders may have the available profit center in home-grown feedstuffs, are closer to the cattle supply, and can in turn also produce cattle destined for AN programs.

Price paid for feeder cattle. In a summary of auction sales from 1995 to 2005 conducted by King, Salman, Wittum, Odde, Seeger, Grotelueschen, Rogers and Quakenbush [21], the average premium for AN cattle was $\$ 2.37 / 45.4 \mathrm{~kg}$. A more recent analysis was conducted by Odde, King, McCabe, Smith, Hill, Rogers and Fike [22], who reported that the premium for AN cattle ranged from $\$ 1.02$ to $\$ 4.04 / 45.4 \mathrm{~kg}$, and AN cattle garnered a statistically greater premium in 7 of the 9 $\mathrm{y}$ used in the analysis compared to calves not sold as AN. Another important consideration is what percentage of cattle that were market as AN feeder cattle were actually fed in an AN program? One must consider if these AN eligible feeder cattle garnered a premium at sale time for a set of reasons other than being AN program eligible, if they ultimately entered the conventional beef production channel.

Estimating fallout salvage value. In a conventional production setting, cattle in feedlots have three potential outcomes, the first is shipment to the primary market, the second is realization of an unthrifty animal to a secondary market (commonly referred to as a "railer" market), and the final outcome is death [27]. For cattle fed in an AN program, the additional outcome of a "fallout" due to antimicrobial treatment is a possibility. When an animal in an AN program is 
treated with an antibiotic, they typically become ineligible for marketing through that AN program and must be removed. Fallout cattle from an AN program are typically treated, then fed, and marketed as NHTC cattle. For NHTC cattle to fall out of their marketing program, they would likely have to be fed a ration contaminated with a beta-adrenergic agonist or melengestrol acetate, inadvertently administered a steroidal implant, or fed corn contaminated with zearalenone.

While there is a premium loss associated with a change in market channel for fallout cattle, these fallout cattle can subsequently have conventional production technologies applied, and there cost of production might be decreased to an unknown degree. However, there is an expected performance loss in any animal that required treatment in the production process. The absolute effect on production is a function of the relative morbidity rate between AN and conventional programs, and the subsequent performance of fallout cattle in the conventional program in order to accurately estimate production cost differentials. If one had direct comparisons of morbidity on a similar class of cattle fed in AN or conventional program, one could determine what system actually leads to increased morbidity between systems. It seems plausible that not using therapeutic would result in increased morbid cattle. Having this information that is dependent upon management systems would allow for more accurate determination of morbidity benchmarks and needed premiums at the time of marketing. Regardless of the fate of these fallout animals, these fallout cattle must be considered in the cost of production to determine what the true differences are in cost of production.

Economic losses associated with fallout cattle can be substantial. The response to application of GET's in fallout animals is unknown and warrants further research if we intended to move away from conventional production methods. Data to estimate these responses is meaningful for accurate comparison of these systems. The salvage value of the fallout cattle is a function of out BW, conventional market pricing, and the rate of realizers in the cattle population relative to realizer value. The weighted average of these two values is an approximation of salvage value for the fallout animal. In most instances mortality would be attributable to origin making the relationship between fallout rates and salvage value difficult to ascertain.

In an AN program the potential for fallout cattle in calf-feds is considerably greater than for yearling cattle because calves tend to have higher rates of morbidity and treatment. Fallout rate can be as high as $20 \%$ to $50 \%$ with calves and $5 \%$ to $10 \%$ with yearling placements in an AN program (T. Milton, personal communication). As transit time and distance increases, animal performance decreases and morbidity increases, even with single-source, ranch raised cattle. Typically, feeder cattle that are eligible for AN programs, whether calves or yearlings, are more expensive than commodity cattle because of the scarcity of program eligible cattle or perceived quality of the cattle. Coupled with purchase premium, the large differences in fallout rate between the two classes of cattle 
favors purchase of yearlings for natural programs. On the other hand, placing only yearling cattle into AN programs, limits the marketing opportunities at different times of the year. It is important to realize that there is a price differential at which the feeder might prefer calves, yearlings, or be indifferent. The factors mentioned above, among many others, determine the size of this spread and thus the decision.

Price received for fed cattle. The primary economic benefit to production of AN or NHTC cattle is a premium received for the fed cattle. These premiums can range considerably but premiums of $\$ 100$ to $\$ 200$ per head are common [28]. Net economics of individual lots of cattle can be evaluated by comparing the potential premium received, compared to additional costs incurred. The price received for the finished beef animal certainly favors AN production. However, depending on price paid for the feeder cattle and whether performance matched expectations, the premium (i.e. breakeven) that one needs to receive at the time of marketing is difficult to estimate between the various feeding regions and production systems used in the North America. Producers and organizations that successfully feed AN cattle are likely able to do so because of the known technical efficiencies of the feedyard and on average, the premiums are greater than the differential costs of production. Due to seasonal differences in AN cattle supply and demand, packers do not have to buy cattle at AN premiums if orders have been filled. This adds another layer of complexity.

\section{Industry and Societal Considerations}

In addition to factors affecting the economic decision of an individual producer, there are industry-wide and societal effects of producing beef using conventional production systems, compared to AN systems.

Health and Safety of Beef. One consideration is the health and safety of the food supply. Any new GET marketed in the US is required to pass a thorough, multi-step scientific review by the US Food and Drug Administration to ensure animal well-being and safety to the human food supply. Use of these compounds must continually be proven safe for human consumption via random testing for residues in edible tissue and potential environmental impacts by way of many independently conducted post-approval environmental impact studies [29] [30] [31]. Health and safety of the beef produced is similar between conventional and AN production systems.

Land Use Considerations. From 1992 to 2012 approximately 12.6 million hectares of US farmland were lost to urbanization [32]. Approximately 4.5 million of the lost hectares were farmland with the most ideal soil conditions, growing seasons, and water availability; allowing for the most intensive production with the smallest environmental impact [32]. Therefore, corn acre usage should also be considered when calculating the overall impact of pharmaceutical technologies and growth technologies. For example, using only steers from Table 5, 28.1 million hd of $590 \mathrm{~kg}$ cattle (AN) would be required to match the beef output of 
25 million hd of $664 \mathrm{~kg}$ cattle (conventional). Conventionally produced steers had a $24.3 \%$ increase in ADG compared to AN steers in Table 5. Initial BW was $378 \mathrm{~kg}$ and 153 days on feed for AN and initial BW was $367 \mathrm{~kg}$ and 177 days on feed for conventional. The resulting ADG was 1.28 and $1.59 \mathrm{~kg} / \mathrm{d}$; with DMI of 9.91 and $9.71 \mathrm{~kg}$. The average F:G for in Table 5 was 7.77 and 6.14 for the AN and conventional steers, respectively. With an estimated DM inclusion of $65 \%$ corn in the finishing diet, assuming the DM of field corn is 85\%, and 153 or 177 days on feed, the resulting as-fed corn intake would be 1159 and $1314 \mathrm{~kg} / \mathrm{hd}$ for the AN and conventional steers, respectively. Total corn consumption for 28.1 million hd of AN steers would be 32.61 billion $\mathrm{kg}$ and for 25.0 million hd of conventional reared steers would be 32.84 billion $\mathrm{kg}$, resulting in 0.23 billion $\mathrm{kg}$ lesser corn consumption by 3.1 million more hd of AN steers. In this example it requires more land to produce conventional beef, however, reducing the number of calves needed to match similar beef production would reduce the required support population, that in turn might allow for a decline in total land use. Also, we can produce more beef with only minimal increases in planted cropland and a reduced need for nearly 3.1 million feeder steers annually. Assuming that the bushel weight of corn is $25.4 \mathrm{~kg}$, and an average yield of $435 \mathrm{bu} / \mathrm{hectare}$ for field corn, then similar levels of beef production can occur with 3.1 million fewer feeder steers and only 19.9 thousand more hectares of corn cropland/yr.

\section{Conclusion}

Pharmaceutical technologies and growth technologies are critical tools to North American and US beef production and consistently offer a positive return on investment by lowering the cost of production resulting in greater gross revenue. Lower cost of beef production increases the likelihood that consumers from various socio-economic classes can enjoy a wholesome, nutrient dense animal protein. The USDA-FSIS monitors levels of various residues in tissues such as muscle and liver, and the risk for residues in meat from animals raised in conventional systems is minute. Pharmaceutical technologies and growth technologies used by beef producers in conventional production systems increase the efficiency of use of available resources, thus, allowing beef to be more competitive in the global protein market. The differences in cost of production and purchase price for AN, NHTC, and USDA-Organic cattle must be recovered in premiums when the cattle are marketed. Magnitude of the premium is dependent upon fallout rate, salvage animal weight and differing costs incurred due to fallout rate. A higher fallout rate might allow for greater salvage out weight and a lower fallout rate might mean limited salvage weight of all fallout animals if treatment is delayed or withheld for a substantial period of time. The management practices used by successful AN feeding programs must not be ignored. There may very well come a time, where the "tools" beef producers routinely use may not be available. In any period of time, cattle feeding enterprises that understand cattle nutritional management and growth biology better than others, are always in a better position than their competitor. 


\section{Conflicts of Interest}

The authors declare no conflicts of interest regarding the publication of this paper.

\section{References}

[1] CRS (2017) The U.S.-EU Beef Hormone Dispute. Congressional Research Service. https://www.everycrsreport.com/files/20170109 R40449 0e4dae241224677cf55efa4 a6430b52eaf84c8ff.pdf

[2] Bartle, S., Preston, R., Brown, R. and Grant, R. (1992) Trenbolone Acetate/Estradiol Combinations in Feedlot Steers: Dose-Response and Implant Carrier Effects. Journal of Animal Science, 70, 1326-1332. https://doi.org/10.2527/1992.7051326x

[3] USDA-AMS (2019) Becoming a Certified Operation. https://www.ams.usda.gov/services/organic-certification/becoming-certified

[4] Reinhardt, C.D. and Wagner, J.J. (2014) High-Dose Anabolic Implants Are Not All the Same for Growth and Carcass Traits of Feedlot Steers: A Meta-Analysis. Journal of Animal Science, 92, 4711-4718. https://doi.org/10.2527/jas.2014-7572

[5] Lean, I.J., Thompson, J.M. and Dunshea, F.R. (2015) A Meta-Analysis of Zilpaterol and Ractopamine Effects on Feedlot Performance, Carcass Traits and Shear Strength of Meat in Cattle. PLoS ONE, 9, e115904.

https://doi.org/10.1371/journal.pone.0115904

[6] Wileman, B.W., Thomson, D.U., Reinhardt, C.D. and Renter, D.G. (2009) Analysis of Modern Technologies Commonly Used in Beef Cattle Production: Conventional Beef Production versus Nonconventional Production Using Meta-Analysis. Journal of Animal Science, 87, 3418-3426. https://doi.org/10.2527/jas.2009-1778

[7] Doyle, E. (2000) Human Safety of Hormone Implants Used to Promote Growth in Cattle: A Review of the Scientific Literature. Food Research Institute, University of Wisconsin: Briefings, Madison, 1-24.

[8] Johnson, B.J. and Beckett, J. (2014) Application of Growth Enhancing Compounds in Modern Beef Production Executive Summary. American Meat Association Reference Paper for 2014, 1-15.

[9] Thompson, A.J., Smith, Z.K.F., Corbin, M.J., Harper, L.B. and Johnson, B.J. (2016) Ionophore Strategy Affects Growth Performance and Carcass Characteristics in Feedlot Steers. Journal of Animal Science, 94, 5341-5349. https://doi.org/10.2527/jas.2016-0841

[10] Smith, Z.K., Thompson, A.J., Hutcheson, J.P., Nichols, W.T. and Johnson, B.J. (2018) Evaluation of Coated Steroidal Implants Containing Trenbolone Acetate and Estradiol-17 $\beta$ on Live Performance, Carcass Traits, and Sera Metabolites in Finishing Steers. Journal of Animal Science, 96, 1704-1723. https://doi.org/10.1093/jas/sky095

[11] Herschler, R.C., Edwards, A.J., Olmsted, A.W., Sheldon, J.J., Hale, R.L., Preston, R.L., Bartle, S.J. and Montgomery, T. (1995) Production Responses to Various Doses and Ratios of Estradiol Benzoate and Trenbolone Acetate Implants in Steers and Heifers. Journal of Animal Science, 73, 2873-2881. https://doi.org/10.2527/1995.73102873x

[12] Pritchard, R.H. and Rust, S. (1997) Interactions of Implant Response with Gender, Age, and Animal Type. Oklahoma Agric. Exp. Sta., Oklahoma State Univ., Stillwater, P-957, 100-104.

[13] Garber, M.J., Hinman, D.D., Miller, J.C., Combs, J.J., Ney, J.J., Eldridge, L. and 
Roeder, R.A. (1990) Efficacy of Vaginal Spaying and Anabolic Implants on Growth and Carcass Characteristics in Beef Heifers. Journal of Animal Science, 68, 1469-1475. https://doi.org/10.2527/1990.6851469x

[14] Main, D.G. (1990) The Effects of Ovariectomy, Growth Promotants and Pubertal Status on Performance of Growing and Finishing Beef Heifers. M.S. Thesis, Michigan State University, East Lansing.

[15] Nygaard, L.J. and Embry, L.B. (1966) Responses of Spayed and Non-Spayed Heifers to Diethylstilbestrol and Synovex Implants. 10th Annual Beef Cattle Field Day, Brookings, Ser. 66-13, Vol. 13, 70-74.

[16] Rupp, G.P., Shoop, M.C., Kimberling, C.V., Bennett, B.W. and Coakley, J. (1982) The Effects of Implants and Spayin on Feedlot Heifers. Unpublished Data.

[17] Rush, I.G. and Reece, P.E. (1981) Spaying and Implanting Growing and Finishing Heifers. 1981 Beef Cattle Report. Nebraska Coop. Ext. Serv. ED81-218. 35-38.

[18] Yamamoto, H.J., Matusushima, J.K., Kimberling, C.V. and Rupp, G.P. (1978) Effects of Spaying and Ralgro Implants on Growing and Finishing Heifers. Beef Nutrition Research. Colorado State Univ. Exp. Sta. General Series 979. 13-14.

[19] Crouse, J.D., Schanbacher, B.D., Cross, H.R., Seideman, S.C. and Smith, S.B. (1987) Growth and Carcass Traits of Heifers as Affected by Hormonal Treatment. Journal of Animal Science, 64, 1434-1440. https://doi.org/10.2527/jas1987.6451434x

[20] Henricks, D., Gray, S., Owenby, J. and Lackey, B. (2001) Residues from Anabolic Preparations after Good Veterinary Practice. APMIS (Acta Pathologica Microbiologica et Immunologica Scandinavica), 109, 273-283. https://doi.org/10.1034/j.1600-0463.2001.d01-120.x

[21] King, M.E., Salman, M.D., Wittum, T.E., Odde, K.G., Seeger, J.T., Grotelueschen, D.M., Rogers, G.M. and Quakenbush, G.A. (2006) Effect of Certified Health Programs on the Sale Price of Beef Calves Marketed through a Livestock Videotape Auction Service from 1995 through 2005. Journal of the American Veterinary Medical Association, 229, 1389-1400. https://doi.org/10.2460/javma.229.9.1389

[22] Odde, K.G., King, M.E., McCabe, E.D., Smith, M.J., Hill, K.L., Rogers, G.M. and Fike, K.E. (2019) Trends in "Natural" Value-Added Calf Programs at Superior Livestock Video Auction. Kansas Agricultural Experiment Station Research Reports, 5, 5-7. https://doi.org/10.4148/2378-5977.7718

[23] Black, D.N., Neville, B.W., Crosswhite, M.R. and Dahlen, C.R. (2015) Evaluation of Implant Strategies in Angus-Sired Steers with High or Low Genetic Potential for Marbling and Gain. Journal of Animal Science, 93, 5411-5418. https://doi.org/10.2527/jas.2015-9296

[24] USDA-NASS (2019) Census of Agriculture United States Department of Agriculture-National Agricultural Statistics Service, Volume 1, Chapter 1: U.S. National Level Data.

[25] Samuelson, K., Hubbert, M., Galyean, M. and Löest, C. (2016) Nutritional Recommendations of Feedlot Consulting Nutritionists: The 2015 New Mexico State and Texas Tech University Survey. Journal of Animal Science, 94, 2648-2663. https://doi.org/10.2527/jas.2016-0282

[26] McCurdy, M.P., Horn, G.W., Wagner, J.J., Lancaster, P.A. and Krehbiel, C.R. (2010) Effects of Winter Growing Programs on Subsequent Feedlot Performance, Carcass Characteristics, Body Composition, and Energy Requirements of Beef Steers. Journal of Animal Science, 88, 1564-1576. https://doi.org/10.2527/jas.2009-2289

[27] Holland, B.P. and Word, A.B. (2018) Can Management Post-Weaning Affect Health Outcomes? Northern States Beef Conference Proceedings, Watertown, 12-13 De- 
cember 2018, 15-22.

[28] Smith, G. (2015) Wulf Cattle Company Finds Success in Value-Added Cattle: The Demand for Value-Added Cattle Continues to Increase. Beef Magazine, 29 October 2015.

[29] Blackwell, B.R., Brown, T.R., Broadway, P.R., Buser, M.D., Brooks, J.C., Johnson, B.J., Cobb, G.P. and Smith, P.N. (2014) Characterization of Trenbolone Acetate and Estradiol Metabolite Excretion Profiles in Implanted Steers. Environmental Toxicology and Chemistry, 33, 2850-2858. https://doi.org/10.1002/etc.2757

[30] Sandoz, M.A., Wooten, K.J., Clendening, S.L., Hensley, L.L., Smith, L.R. and Smith, P.N. (2018) Transport Mechanisms for Veterinary Pharmaceuticals from Beef Cattle Feedyards to Wetlands: Is Aerial Deposition a Contributing Source? Agriculture, Ecosystems \& Environment, 252, 14-21. https://doi.org/10.1016/j.agee.2017.09.016

[31] FSIS (2019) Red Book: Residue Results. https://www.fsis.usda.gov/wps/portal/fsis/topics/data-collection-and-reports/chemi stry/red-books/red-book

[32] Theobald, D.M., Leinwand, I., Sorensen, A. and Dickson, B.G. (2018) Description of the Approach, Data, and Analytical Methods Used for the Farms under Threat: The State of America's Farmland Project. Final Report, Conservation Science Partners, Inc., Truckee.

[33] Maxwell, C.L., Grimes, A.N., Bernhard, B.C., Wilson, B.K., O’Neill, C.F., Hixon, C.G., Richards, C.J., Haviland, C.L., VanOverbeke, D.L., Mafi, G.G., Calvo-Lorenzo, M.S., Krehbiel, C.R., Step, D.L. and Holland, B.P. (2015) The Effects of Technology Use in Feedlot Production Systems on Feedlot Performance and Carcass Characteristics. Journal of Animal Science, 93, 1340-1349.

https://doi.org/10.2527/jas.2014-8127 